\title{
Feasibility study for waterway infrastructure: international overview and methodological recommendations
}

\author{
Lílian dos Santos F. P. Bracarense ${ }^{\mathrm{a} *}$, Rayssa Brandão ${ }^{\mathrm{b}}$, Yaeko Yamashita ${ }^{\mathrm{b}}$, Joaquim José \\ Guilherme de Aragão ${ }^{\text {, }}$ \\ ${ }^{a}$ Universidade Federal do Tocantins, Palmas-TO \\ ${ }^{b}$, Brasil Universidade de Brasília, Brasília-DF, Brasil
}

\begin{abstract}
The context in which the waterway transportation is in Brazil makes clear the development need of specific methodologies for the sector planning. This paper aims to compare the methods of analysis of technical, economic and environmental viability, adopted in Europe, United States and Brazil, listing the best practices and possible improvements of the method adopted in Brazil. The analysis of the documents was based on comparative method, seeking the common elements from its attributes. Each document was analysed in terms of: its structure; type of impacts; required indicators on each impact analysis; reference values for classification of indicators; and the form of integrated analysis of different impacts. The study suggests the inclusion of certain changes in the methodology of calculation and in its combination of tools and parameters used in the measurement of fiscal impacts on the comparative analysis of standard models usually adopted in the United States, Europe and the World Bank.
\end{abstract}

\section{Introductin}

Brazil presents great potential for river navigation use, with about $63,000 \mathrm{~km}$ of rivers, lakes and ponds. Of that, more than 40,000 km are potentially navigable. However, commercial navigation occurs in little more than 13,000 $\mathrm{km}$, with the Amazonian Region hosting a significant amount of the river area (Brasil, 2010). 
Despite the vast navigability possibilities, infrastructure bottlenecks within this transportation mean require the execution of suitableness construction work, improvement, and especially maintenance of the waterways. These interventions and the waterway operation itself might generate environmental impacts that need to be well studied. At this juncture, the National Environmental Policy instruments are applied in feasibility and environmental impact assessment studies, and environmental licensing.

As defined by Dalbem et al. (2010), on the private sector point of view a project feasibility is proven by a monetary analysis comparing the expected revenues and the investment and operation costs, where the first is predominant. Also, the project must be financially attractive in face of other investment options. From society's point of view, however, other factors other than revenue generation might be considered to be beneficial in a project implantation, such as sector or regional economic development, life quality improvement, transportation time and accident reduction benefits, among others. Thereby, in an economic assessment context, even if a project does not generate the financial return required by the private investor, it can still be interesting society wise. The first studies regarding feasibility assessment methodologies were started in Europe and the U.S. in the 1950s. In Brazil they are a little more recent and remarkably inspired by the precursor's models.

The context on which the Brazilian water transport is inserted highlights the necessity for the development of specific methodologies for the sector planning. This article aims to compare technical, economic and environmental feasibility analysis methods adopted in Europe, the U.S. and Brazil, listing best practices and possible improvements in the Brazilian method.

\section{The waterway dilemma and feasibility studies}

Analyzing the national scenario of the Brazilian waterway system, Pompermayer et al. (2014) indicates that, despite not fully explored in regards to its potential and few financial resources effectively applied, at the federal level, there is the simultaneous presence of seven plans and programs under the coordination or direct responsibility of eight institutions. In this context of overlapping of responsibilities, the basic tools that allow access to information and knowledge necessary for the preparation of planning documents, Technical, Economic and Environmental Feasibility Studies (EVTEAs), are still in preparation.

In terms of infrastructure and operation, the waterway system incurs specific risks that are distinct from terrestrial systems, for example the water crisis. The implementation, operation and revenue forecast costs directly associated with the demand and profile of the transported load must also be carefully analyzed. On Valente's point of view (2013), "the main challenge in waterway transportation is to assert the construction of locks in reservoirs and dams to allow total navigability in the most important rivers of the country." The author also points out the divergence of interests within the electricity sector, which refuses to pay lock construction costs that might enable waterway use.

Besides this conflict, Carvalho (2008) presents possible impacts arisen from implementation activities, not very common in terrestrial systems, which are already consolidated in the country. As regards to the aquatic environment, deforestation, excavation and dragging operations might generate temporary or permanent animal disturbance, deaths by burial and/or sedimentation. It may occur material suspension, which increases water turbidity consequently reducing light penetration followed by alterations in the aquatic biota. Weir's construction modifies flowing river conditions and has influence on the flood in adjacent areas which, by its turn, affects the animal and human population there installed. Waterway course adjustment and channel construction might increase the flowing water velocity, sediment disaggregation in riverbeds and banks, sudden volume variations of transported sediments and elevation in silting and turbidity levels. Moreover, vessel traffic turns around suspended sediment load from the bottom of fluvial channels and increases erosion rates of river margins in more critical areas, not to mention the higher emission of atmospheric pollutants and possibility of contamination in the aquatic media because of ballast waters waste or inadequacy in loads handling.

The waterway specificity highlights the necessity of involving different knowledge areas on project assessments and expanding out the support analysis to the decision makers. Like Pompermayer et al. (2014) emphasize, the waterway sector is relatively unknown by the public and private sectors, in Brazil. Therefore, it cannot draw 
attention to more powerful authorities to decide on its favor in terms of the establishment of public politics and resources allocations.

Despite the disturbed institutional scenario, a study developed by Pompermayer et al. (2014) demonstrates that waterway transportation is the most adequate to receive public resources to implement its infrastructure, if freights and costs of waterway and rail and road transportation are compared and also considering the natural navigation conditions of Brazilian rivers and lakes. It is also important to point out that waterway transportation in Brazil almost exclusively depends on fiscal resources. The scenario refers to the urgency in the development of planning methods applied to the waterway context starting from the understanding of its peculiarities.

\section{Project Feasibility Studies: Comparative evaluation}

Nowadays, feasibility studies for transportation infrastructure projects comprise Technical, Economic and Environmental Feasibility Studies (EVTEA), by which the costs and benefits of alterations that will happen in the environment and in social and economic spheres regarding a project choice will be monetarily quantified.

Aiming to evaluate the feasibility analysis procedure applied in Brazil with reference to the international scenario, a qualitative research was made regarding the following subject-related reference documents: Principles and Requirements for Federal Investments in Water Resources (USA, 2013), Manual of costs and benefits analysis of investment projects (European Commission, 2003), Handbook on economic analysis of investment operations (World Bank, 1998) and Presentation Manual of Feasibility Studies of Great Proportion Projects (Brazil, 2009).

The American document, here referred as PRG-USA, is a public law that superposes the previous document Economic and Environmental Principles and Guidelines for Water and Related Land Resources (1983). Its main objective is to constitute a standard framework on the water resources area to formulate, evaluate and compare a variety of projects, programs and activities that direct or indirectly affects the water quantity or quality and that involves federal investment. To better understand how the feasibility studies are carried out and applied in the United States through the PRG-USA, the Interagency Guidelines (USA, 2014) document was also analysed.

The European manual (MCB-UE) was developed as the European Commission needed to evaluate the appreciation quality of projects made by Member-States before their co-finance. It facilitates the dialog and transparency between stakeholders by having common appreciation language as a premise.

The World Bank document (HEA-WB) aims to provide analytical tools founded on the economic theory to increase the economic assessment transparency of projects. The TRN-8 - The fiscal impacts of transport investment (World Bank, 2005) was additionally analysed.

The Brazilian manual (MEV-BR) was elaborated by the Ministry of Planning, Budget and Management to guide the sectorial bodies present the studies financed by state-owned organizations which value is equal or superior than $\mathrm{R} \$ 100$ million or by the government fiscal budget which equals or surpasses $\mathrm{R} \$ 20$ million to the Technical Chamber of Great Proportion Projects.

The documents analysis was made through a comparative method, seeking confrontation between common attribute elements. Each document was assessed in regards to its: structure, tackled impacts, required indicators for the analysis of each impact, reference values for indicators classification, and the integrated analysis way of different impacts. The main resulted considerations of the comparison are presented below.

\subsection{Structure}

In regards to the structure, the methods are similar. Broadly speaking, all the methods enclose objective definition, initial diagnostic analysis, alternatives formulation, impacts evaluation, and financial, economic and environmental analysis. The European method (MCB-UE) details the content that could be compared to the diagnostic step of the other methods and doesn't clearly define a step dedicated to alternatives formulation. The HEA-WB is the only method that inserts the fiscal impact evaluation on the study structure. While the American, European and World Bank methods require risk and sensibility analysis, the Brazilian method specifies a managing analysis that contemplates risk, sensibility and monitoring analysis. 


\subsection{Impacts}

All the methods require the identification of environmental and socioeconomic impacts. The HEA-WB highlights the need of identifying the stakeholders - beneficiaries and disadvantaged by the project - on the impact analysis. The document also demands the fiscal impact assessment of the project, seeking to determine: the cost recovery by its beneficiaries; changes in public expenses and budgets embedded in the project; net effect for the central and local government; effect of costs recovery arrangements on the demanded quantities of service, benefits distribution and efficient use of project results and other resources; and the portion of non-recovered costs.

About this aspect, Dalbem et al. (2010) features the fiscal impacts of a project are bigger than the ones actually disbursed, since public resources have a marginal cost. Thus, a project that makes net use of public resources has its net present value (NEV) reduced by this effect, while a projects that is a net generator of public resources has its $\mathrm{NEV}$ increased. It is not always simple to estimate these effects, but in cases where the project demands public resources and has a low NEV this effect might change the decision and should, therefore, be estimated.

\subsection{Indicators}

In general, all the methods are flexible about the environmental and socioeconomic indicators. However, they do not specify further calculation methods.

The PRG-USA underlines a broader range of indicators. Agencies must use indicators that apply to the investment's nature and that are in agreement with the Guide Principles for further evaluation and comparison of viable alternatives. Some indicators are applied in frameworks such as: resilience of ecosystems; risk reduction of wetland flood modification; public security risk; environmental and public health (social) in underprivileged communities; watersheds conditions and needs; sustainable development (economic, social and environmental indicators).

The other documents are less comprehensive and focus on sustainable development indicators analysis. They differ from the American manual for presenting indicators directly related to investments in transportation infrastructure, such as: transit flow; demand transference for other transportation means that are less pollutants; human lives saved by the project on the health sector; saved time by the project on the transportation sector including congestion reduction; and accessibility (MCB-UE, HEA-WB). The Brazilian manual does not mention any specific environmental indicator, but draws attention to the evaluation of impacts mitigation actions to be inserted on the project.

\subsection{Reference values and assessment methods}

The pointing out of reference values in all documents is limited to economic analysis indicators, such as discount tax and IRR (PGR-USA, MCB-UE, HEA-WB). Besides those, the documents refer to some reference values for impact monetization like time saving (MCB-UE, HEA-WB) and life appreciation. (HEA-WB, MEV-BR).

The American document determines that agencies must transmit their approach within "Agency Specific Procedures" with the total understanding that methodologies change over time and with science development. The analysis must always try to incorporate the best science and methodology available at the moment. Agencies are also encouraged to examine the available literature for relevant applications and potential additional metrics. This standing guarantees flexibility to the analyses, however when combined to the high range of possible variables to be used, it contributes to more imprecision on the analysis. This is why risks and uncertainties regarding the made analysis must be identified, considering future conditions and potential effects of every alternative.

The risk analysis must cover the nature, probability and magnitude of risks, as well as the description of uncertainties associated with data, projections and alternative evaluations so that risk and uncertainty reduction is considered on the alternatives formulation and final decision.

In addition to the risk analysis, the sensibility analysis evaluates the variation of profitability indicators according to different alternatives, using some key variables that allow fidelity control of the obtained results, classification of 
any other fee, and identification of higher risk areas. It's based on monetary values attributed to non-commercialized goods, because they are the most contestable ones. Another sensibility analysis may focus, for example, on investment and operation costs or on expected demand, especially generated traffic.

The fiscal impact analysis is presented in HEA-WB, incorporating information about:

- $\quad$ Fiscal policies needed for macroeconomic stability;

- Extension and way the project costs will be recovered by the beneficiaries;

- Public expenses and revenues changes applicable to the project;

- Net effect for the local and central government;

- Accounting of the non-retrievable portion of the investment

It also recommends that the effect of public resources marginal cost be considered, and that the project costs recovered through taxes, that represent a society cost (approximately, 30\%), be discounted from the net benefits of the project. Preferably, the costs must be recovered directly from the beneficiaries through user fees instead of from a system based on taxes collection.

Besides the methods of variables quantification, another point that deserves attention is regarding the alternatives evaluation method. The PRG-USA defines that the evaluation framework must be common to all investments. The relationship public benefits $\mathrm{x}$ costs must be verified based on ecosystemic provisioning services, regulatory and cultural. Usage changes of these services must be quantified and monetized when possible, including the concepts of Discount Rate, Opportunity Cost and Willingness to Pay. Services that cannot be quantified should be qualitatively described in sufficient detail so that the decision maker understand the importance and magnitude of the changes.

Alternatives comparison must be made based on Display and Trade-offs analysis. The first one consists of graphics, tables, drawings, photography, summary statements or another impacts indications. The chosen display method must be the same for all alternatives and must present each alternative's performance related to the base-line, study objectives, formulation criteria, and any other selection criteria used on the analysis. The Display helps the public and the decision maker understand similarities and differences between alternatives and their effectivity in corroborating with the project proposals, and the trade-off in quantifiable and non-quantifiable benefits and costs between alternatives.

\subsection{Integrated analysis of impacts}

Once the impacts are determined, integrating the analysis in a way that positive and negative aspects are balanced and making a decision regarding the project implantation make some difficulties emerge, especially in respect to the impacts that could not be monetized at the end of the assessment. Non-monetized and non-quantifiable effects are generally included on the general analysis process, but are not necessarily properly pondered or considered key elements on the final decision making process. Therefore, decision making processes tend to go towards the more easily quantified and monetized effects.

The American document, PRG-USA, establishes some premises for the integrated evaluation of impacts: a) Environmental, economic and social impacts are interrelated and a hierarchy between their objectives does not exist; b) Qualitative impacts may be considered with the same importance that monetized ones are.

The MCB-UE understands the cost-benefit analysis as the promoter of the integration between environmental, socioeconomic and financial analysis. Multicriteria analysis must be employed to allow the balance between quantifiable and non-quantifiable aspects. The comparison between economic and financial analysis must be followed up by the identification of divergence sources between them. The Brazilian document, by its turn, has the environmental and socioeconomic impacts in the economic analysis with no further considerations regarding the non-quantifiable aspects. 


\section{Recomendations}

The Brazilian waterway system conjuncture reveals deprivation of precise information, that could give support to the planning decisions and allow effective actions to be taken. At this phase, feasibility studies are of significant importance to determine what should be included on the government agenda.

As regards the analysed documents, it is noticeable that the Brazilian manual treats subject questions superficially, therefore constituting a generic document in which indicators and methods to be adopted must be defined for every project. This characteristic brings flexibility so that it can be adopted as a guide for projects of a wide range of nature. However, since it applies to a sector that demands more specific analysis, like the waterway sector, is noticed a lack of a document that can offer directed support to the sector for assessment elaboration.

Some structural recommendations may be highlighted in order to construct more robust analysis for waterway projects:

- Initially, the environmental impact assessment requires inclusion of indicators applied to waterway systems inspired by the PGR-USA, considering the multiple use of waters, such as: availability and efficiency of use and water quality; nutrient regulation; floods and droughts incidence; impacts in aquatic and riverside habitats; biodiversity maintenance alternatives; current and future projected tendencies for the utilization of waterways; removal of riverbed material, soil and sediments (dredging, construction/extension of access ways, port terminal implantation, etc.); unstableness of hillsides and erosions;

- The complex character and the multiplicity of impacts related to the implantation of a waterway make the stakeholders analysis important on the distribution of costs and benefits, proposed in HEA-WB, as well as more attention and detailing dedicated to indirect impacts, including developed areas.

- The waterway systems require high implementation costs comprising since regularization work of the bedside like dredging and rock blasting, level transposal (commonly via canal lock), signalization, port infrastructure. In times of resources retention, it is highly recommended that planning and infrastructure projects assessments begin to include a new type of appraisement, the fiscal economic impacts evaluation, not only the direct ones, but also the indirect (i.e. produced in supply chains) and induced (produced by the purchasing power generated by total employment in the project and supply chains). This kind of assessment, differently from the current economic feasibility studies that focus on user and neighbouring community benefits) would allow to visualize the fiscal balance of the project. If it is positive, the exclusion of the project from further cut-offs of fiscal adjustments imposed by the Fiscal Responsibility Law would be justified.

- Risk and sensibility analysis that, even though present in the Brazilian manual, requires more detailing regarding the minimal criteria to be verified to be consider enough, like in the PGR-USA example. Specific risks to waterway activity must be taken up, like the hydrologic and accident with spill of transported loads risks, and the possibility of water media contamination with ballast water.

Finally, the integrated assessment of impacts, procedure used to include non-quantifiable results on the evaluation, deserves attention. The multicriteria analysis suggested by MCB-EU is a solution frequently adopted in Brazil, however it is worth highlighting the importance of stakeholders participation on the process, in order to guarantee more realistic results.

\section{Acknoledgements}

The authors thank CNPq and FAPDF for the financial support.

\section{References}

Brasil. Ministério dos Transportes, 2010. Diretrizes da Política Nacional de Transporte Hidroviário. Brasília.

Brasil. Ministério do Planejamento, Orçamento e Gestão. Comissão de Monitoramento e Avaliação do Plano 
Plurianual, 2009. Câmara Técnica de Projetos de Grande Vulto. Manual de apresentação de estudos de viabilidade de projetos de grande vulto. Versão 2.0. Brasília: MP, 2009. 52p.

Carvalho, F. S., 2008. Análise Multicritério de Projetos de Transporte Hidroviário Interior. 194 p. Tese. Universidade Federal do Rio de Janeiro. Programa de Engenharia Oceânica. UFRJ/COPPE. Rio de Janeiro.

Comissão Europeia, 2003. Manual de análise de custos e benefícios dos projetos de investimento. Bruxelas: CE $155 \mathrm{p}$.

Dalbem, M. Brandão, L. and Macedo-Soares, T. D., 2010. Avaliação econômica de projetos de transporte: melhores práticas e recomendações para o Brasil. Revista de Administração Pública, Rio de Janeiro, v. 44, n. 1, p. 87-117, jan./fev. 2010.

Pompermayer, F. M., Campos Neto, C. A. S., Paula, J. M. P., 2014. Hidrovias No Brasil: Perspectiva Histórica, Custos e Institucionalidade. Texto para discussão. Instituto de Pesquisa Econômica Aplicada.- Brasília : Rio de Janeiro : Ipea , 1990-

United States Of America. Executive Office of the President. Office of Management and Budget; Council on Environmental Quality, 2013. Principles and Requirements for Federal Investments in Water Resources. Washington: EOP, 16p.

United States Of America. Executive Office of the President. Office of Management and Budget; Council on Environmental Quality, 2013. Interagency Guidelines. In: Investments in Water Resources. Washington: EOP, mar. 2013. Ch. 3.

Valente, J. A., 2013. Infraestrutura, transportes e mobilidade territorial / José Augusto Valente (org.). Editora Fundação Perseu Abramo, São Paulo.

World Bank, 1998. Handbook on economic analysis of investment operations. WBH. 209p.

World Bank, 1998. TRN-8. Transport Notes. Fiscal impacts: the fiscal impacts of transport investments. Washington: WB, jan. 2005. 4p. 